\title{
Settlement, movement and early juvenile mortality of the yellowtail snapper Ocyurus chrysurus
}

\author{
M. Watson, J. L. Munro*, F. R. Gell \\ ICLARM Caribbean/Eastern Pacific Office, 158 Inland Messenger, Road Town, Tortola, British Virgin Islands
}

\begin{abstract}
Visual censuses of recently settled yellowtail snapper Ocyurus chrysurus were made within a grid measuring $50 \times 25 \mathrm{~m}$ established in a $<1 \mathrm{~m}$ deep seagrass (Thalassia testudinum) bed in the British Virgin Islands, eastern Caribbean, between September 1999 and July 2000. A peak of 92 newly settled O. chrysurus was observed around the new moon in September 1999, followed by a decline of more than $75 \%$ over $3 \mathrm{wk}$. Light trapping near adjacent fringing reefs documented a concurrent pulse of late pelagic stage O. chrysurus. Observations in April-May and June-July 2000 recorded much smaller supply events and lower settlement densities. The effects of post-settlement movement, as opposed to early mortality, were assessed and concluded to be negligible. Firstly, fish $<8 \mathrm{~cm}$ total length were consistently observed in the seagrass but were never recorded in censuses of adjacent rocky habitat, where older juveniles occurred. Thus, settlement-stage fish were assumed to reside in seagrass for several weeks. Second, average home ranges for fish of 2 to $2.5 \mathrm{~cm}$ and 3 to $3.5 \mathrm{~cm}$ total length were estimated to be $2.3 \mathrm{~m}^{2}$ and $6.3 \mathrm{~m}^{2}$, respectively, indicating that movement of newly settled $O$. chrysurus was negligible compared to the size of the census area $\left(1250 \mathrm{~m}^{2}\right)$. Third, late pelagic-stage $O$. chrysurus caught with light traps in adjacent waters were tagged with fluorescent elastomer and released at the center of the seagrass grid the evening after their capture. Ninetysix individuals were released over 3 evenings in September 1999. Concurrent aquarium studies showed tagging mortality was $13 \%$. Over the following $8 \mathrm{~d}, 32$ re-sightings were made. Only 1 fish was seen more than 2 to $3 \mathrm{~m}$ distant from where it was sighted on the first census after releases were completed, providing convincing evidence of site fidelity after settlement. Using a simple model, we conservatively estimated the coefficient of daily mortality, $M$, at settlement to be about 0.28 (equivalent to $76 \%$ survival $\mathrm{d}^{-1}$ ) and to reduce by 0.042 thereafter.
\end{abstract}

KEY WORDS: Caribbean $\cdot$ Coral reefs $\cdot$ Fisheries $\cdot$ Elastomer $\cdot$ Recruitment

\section{INTRODUCTION}

The numbers of maturing individuals in a marine fish or invertebrate population is the cumulative result of pre-settlement and post-settlement mortality rates, but these rates are poorly known. Losses during the planktonic and pelagic stages of coral reef fish are thought to average about $20 \% \mathrm{~d}^{-1}$ (Cowen et al. 2000), and Doherty et al. (unpubl.) have estimated that $60 \%$ of settling Naso unicornis are lost to predators during the

${ }^{*}$ Corresponding author. E-mail: j.munro@cgiar.org night of settlement from the pelagic zone. Post-settlement mortality rates have been better studied (Sale \& Ferrell 1988, Caley 1998), and there is an increasing appreciation of the intense and often variable effects of post-settlement predation on subsequent population size (Shulman \& Ogden 1987, Hixon \& Beets 1989, 1993, Caley 1993, 1995, Carr \& Hixon 1995, Forrester 1995, Beets 1997, Forrester \& Steele 2000). Pluralistic models of fish population dynamics may be most appropriate (Menge \& Sutherland 1987, Jones 1991, Hixon \& Beets 1993, Doherty \& Fowler 1994, Beukers \& Jones 1997, Connell 1998, Levin 1998, Caselle 1999). However, there are relatively few direct estimates of 
early juvenile mortality, partly because it is difficult to separate early mortality from post-settlement movement (Frederick 1997a).

It is well established that fishes and other aquatic organisms can be recruitment-limited and that settlers often do not seem to saturate their environments (reviewed by Doherty \& Williams 1988, Booth \& Brosnan 1995, Munro \& Bell 1997). In heavily fished regions, the effects of recruitment limitation on selected commercially exploited fish may be exacerbated as a result of recruitment overfishing (whereby adult stocks are fished so hard that their reproductive output is insufficient to sustain historic population levels) whether or not high post-settlement mortality obscures any obvious relationship between abundance at settlement and adult population size (Jennings \& Lock 1996 and references therein). For fish stocks that may be recruitment-limited, connectivity is important in determining recovery from disturbances including fishing (Doherty \& Fowler 1994). In isolated stocks that only occasionally receive larval recruits from distant sources, severe overfishing can lead to recruitment collapse. For example, Munro \& Watson (1999) and Watson \& Munro (unpubl.) show that the supply of commercially important fish larvae to the heavily overexploited Discovery Bay in Jamaica is severely depressed and recruitment of juvenile fish has been consistently low in recent years. Such populations may take decades to recover even if no-fishing zones (such as one recently implemented in Discovery Bay) are established. Even where spawning stock biomasses appear to be relatively large, settlement and recruitment rates remain highly variable, temporally and spatially.
Recruitment limitation introduces the possibility of enhancing populations through artificial stocking (Doherty \& Fowler 1994, Munro \& Bell 1997, Doherty 1999). Alternatively, where mortality is high, measures aimed at boosting early juvenile survival may also help restore populations. Artificial stocking has been severely criticized in many fisheries as uneconomic (Hilborn 1998), inappropriate (Scarnecchia 1988, Meffe 1992), difficult to evaluate (Leber et al. 1996, Hilborn 1998) and potentially harmful to wild populations through introduction of disease or through genetic selection for inappropriate characteristics (Schramm \& Piper 1995). But despite these criticisms, stock enhancement may be the most appropriate option where wild stocks are essentially gone (Hilborn 1998), such as in reef fisheries suffering recruitment collapse. Doherty (1994) first proposed light traps as a means to gather larval reef fish for stock enhancement. Watson et al. (2001) suggested gathering available late-stage larval reef fishes with light traps and subsequently rearing fish for several weeks in order to by-pass the high mortality hurdle typical of early juvenile life (Roberts 1996 and references therein). Juveniles could then be released into no-fishing areas in order to accelerate population recovery.

However, assessing the feasibility of such an approach requires a good understanding of the juvenile life history of target species. Such information is scarce for many reef fishes (McCormick \& Makey 1997) and especially for commercially important species such as snappers, grunts and groupers (but see McFarland et al. 1985, Shulman \& Ogden 1987 for grunts and Shenker et al. 1993, Eggleston 1995 for groupers, Nagelkerken et al. 2000a,b, 2001). Indeed,
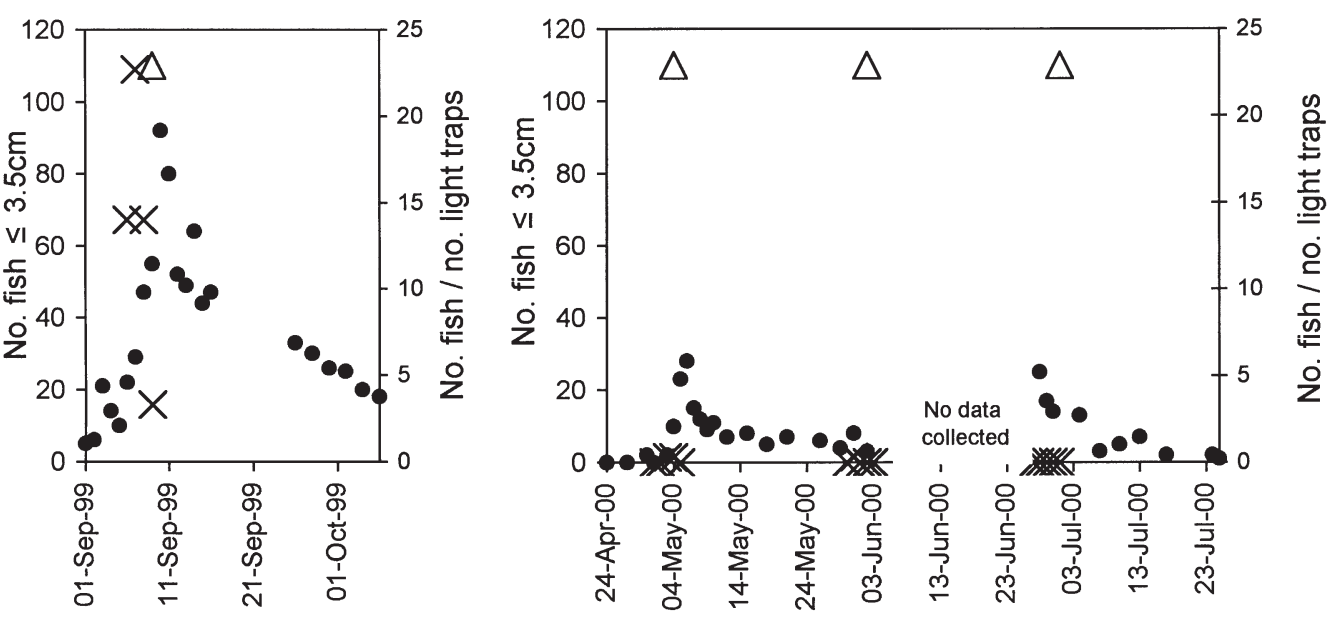

Fig. 1. Number of early juvenile Ocyurus chrysurus ( $\bullet$, scale on the primary axis) observed within $1250 \mathrm{~m}^{2}$ of shallow seagrass, and average catch of late pelagic stage $O$. chrysurus larvae taken in light traps at a neighbouring study site $(\times$, and scale on secondary axis), all plotted against date. $(\Delta)$ New moon 
the majority of recruitment and early juvenile mortality studies have concentrated on small solitary and territorial species (McCormick \& Makey 1997, Booth \& Wellington 1998, Caley 1998).

The yellowtail snapper Ocyurus chrysurus is one of the most important and heavily targeted reef fishery species in the Caribbean. In this study, we investigate the first month of post-settlement life in shallow seagrass nursery areas with underwater visual census techniques. We separate early juvenile mortality from movement by answering the following specific questions: (1) Are settlement-stage $O$. chrysurus resident in seagrass? (2) Do early juveniles maintain a home range and, if so, how does home range vary with fish size? (3) Is such a range stable? Using a simple model to explain changes in mortality over time, we provide the first experimentally derived estimates of natural mortality at settlement for this species and thus generate a natural mortality baseline against which to compare survival in short-term rearing systems, and the likely success of release programs.

\section{MATERIALS AND METHODS}

Settlement. Settlement peaks and subsequent declines in abundance of Ocyurus chrysurus were monitored by censuses of a $50 \times 25 \mathrm{~m}$ grid in a shallow seagrass (Thalassia testudinum) bed at the eastern end of Tortola, British Virgin Islands. Three surveys were made. The first 2, in September-October 1999 and April-May 2000, started around the last lunar quarter. The third survey, in June-July 2000, started at new moon. The grid was marked into $5 \times 5$ m squares with thin nylon cord pinned to the substrate. One observer swam concentrically around each individual square until the entire area was censused, before moving on to the next square. If it was suspected that a fish had already been counted in a different part of the square or adjacent squares, the observer looked for the previously noted fish and only counted both if they could be seen simultaneously. Censuses of the total area took 2 to $2.5 \mathrm{~h}$.

The total length (TL) of each fish was estimated to the nearest $0.5 \mathrm{~cm}$ and its position within the square was noted. A scale drawing of the grid on the observer's slate (where $5 \mathrm{~m}$ was represented as $2.5 \mathrm{~cm}$ ) provided a guide for length estimation. In addition, small fish usually remained stationary long enough to gauge their size against a background feature, allowing the observer to measure that if the size was uncertain. Estimates were probably less accurate for more mobile fish $>5 \mathrm{~cm}$.

It was known from previous light trapping work (Watson \& Munro unpubl.) that Ocyurus chrysurus settles from the pelagic phase around new moon at 1.5 to $2.5 \mathrm{~cm}$ (modal size $2 \mathrm{~cm}$ ) and this was confirmed by these observations. With the exception of the JuneJuly data set, sampling began before new moon when very few fish were on the grid, confirming that cohorts did not overlap significantly. Sampling was most extensive in September-October, when we censused until $26 \mathrm{~d}$ after peak settlement. We chose this cut-off to avoid biases due to new influxes, although in fact negligible new settlement was observed (October appears to be the end of the recruitment season in Tortola [Munro \& Watson 1999]). Actual sampling frequencies ranged from daily around the new moons to $4 \mathrm{~d}$ approaching the last quarter moon, but there was a $10 \mathrm{~d}$ break between moon ages 7 to 17 in September 2000 for logistical reasons (Fig. 1). So few settlementstage fish were recorded around the new moon at the end of May that sampling was discontinued until the following new moon period.

Temporal patterns in abundance were assumed proportional to settlement and natural mortality plus movement (as in McGehee 1995). The distribution of settlers at peak abundance for each of the 3 lunar cycles sampled was examined for random, clumped or uniform patterns using the chi squared test. Catches of Ocyurus chrysurus from light traps set in deeper water as part of a separate study during the 4 to $5 \mathrm{~d}$ preceding each new moon were examined for concurrent peaks in the supply of pre-settlement postlarvae.

Movement. Our assumption was that likely movements of newly settled Ocyurus chrysurus were negligible compared to the overall size of our sample area $\left(1250 \mathrm{~m}^{2}\right)$ and that immigration across the boundaries equaled emigration. We tested this assumption with various techniques.

(1) To assess whether settlement-stage $O$. chrysurus were resident in the seagrass, length frequencies from the grid censuses were compared with concurrent visual censuses of an adjacent rocky habitat where older juveniles shoaled during the day. (2) To investigate the home range of early juvenile $O$. chrysurus in each of size classes 2 to $2.5,3$ to $3.5,4$ to 4.5 and 5 to $5.5 \mathrm{~cm}$, individuals on the grid $(\mathrm{n}=11,7,4$ and 4 in each size class, respectively) were monitored for 30 min each and their positions marked every minute by dropping a coloured coin. The coins were then mapped using the grid squares for reference, and home range was estimated by the convex polygon method (Odum \& Kuenzler 1955). This study was undertaken in September 1999. However, although daytime home range could be estimated, the study did not demonstrate whether individuals showed any site fidelity or whether they adopted a new but circumscribed home range erratically. (3) Therefore a third set of observations was made. In September 1999, pre- 
settlement $O$. chrysurus caught in light traps were tagged with fluorescent orange elastomer, injected behind the dorsal fin, following the methods described in Frederick (1997b). On 6, 7 and 8 September, a total of 96 fish, approximately $2 \mathrm{~cm} \mathrm{TL}$, were put in a small mesh cage at the center of the grid at dusk on the night following capture in light traps. The fish initially schooled together in the water column. The cage was weighted so that 1 side regularly lifted off the ground in the current. Thus, as fish moved from the water column to the benthic habitat they could escape. The cage was removed the following morning, by which time any remaining fish had orientated to the substrate, and they quickly dispersed when their cover was removed. The positions of elastomer-tagged fish were recorded on subsequent censuses and compared between dates to determine whether settled fish were repeatedly seen at the same location. Forty-seven tagged fish were kept in aquaria for $48 \mathrm{~h}$ to study tagging effects. Mortality was $13 \%$ over the first $24 \mathrm{~h}$ and negligible in the subsequent $24 \mathrm{~h}$. This is very similar to Frederick's (1997b) study. (4) In a fourth set of observations, 23 elastomer-tagged $O$. chrysurus were released inside a $16 \mathrm{~m}^{2}$ area, enclosed by a $45 \mathrm{~cm}$ high fence of $5 \mathrm{~mm}$ mesh, at the center of the experimental grid. The fence extended well above the seagrass, thus fish would have to re-enter the water column to cross it. The positions of elastomer-tagged fish either inside or outside the fence were recorded on 12 subsequent censuses up to 23 d later.

Mortality. Once we had separated any effects of movement from the census estimates (see 'Results' and 'Discussion'), abundance was considered proportional to survival, allowing us to calculate the proportion of fish surviving the first 3 to 4 wk after settlement. Settlement was highly pulsed in the 5 nights preceding and including the new moon, when the numbers of fish in the 1.5 to $2 \mathrm{~cm}$ size classes peaked. Thereafter, no fish in the $1.5 \mathrm{~cm}$ size class were seen and very few fishes in the $2 \mathrm{~cm}$ size class were observed. Some large $(>2 \mathrm{~cm})$ new recruits probably arrived in the days after the numbers of fish in the study area had peaked, and mortality rate calculations based on the apparent decline in abundance of a cohort will therefore tend to underestimate the actual mortality rate to some degree.

Extremely high rates of mortality of coral reef fish have been reported in the days following settlement from the plankton (Shulman \& Ogden 1987, Sale \& Ferrell 1988, Roberts 1996 and references therein, Planes \& Lecaillon 1998, Caselle 1999) and the steady natural mortality rate, $M$, that is conventionally used to describe the death rates of adult fish, is clearly inapplicable to early post-settlement fish. We postulated that mortality rates could be expected to decrease from a high initial value as post-settlement juvenile fish become adapted to their new environment and the survivors become more skilled in avoiding predators. If this is true and there is no abrupt ontogenetic change in mortality rates, the cumulative number of deaths would increase asymptotically until the entire cohort is dead, and the final mortality rate would be that of large, old, healthy fish. If there were an abrupt change in mortality rates, for example with the change from juvenile to adult habitat, then a series of asymptotic curves would be expected.

Thus, if the cumulative number of deaths increases asymptotically over time:

$$
D_{t}=\mathrm{N}_{\mathrm{r}}\left(1-\mathrm{e}^{-(M+m \cdot t)}\right)
$$

in which $D_{t}$ is the cumulative number of deaths at time $t, \mathrm{~N}_{\mathrm{r}}$ is the initial number of fish in a single cohort that settles at $t=0, m$ is the amount by which the initial mortality rate, $M$, decreases each day. $D_{t}=\mathrm{N}_{\mathrm{r}}$ at $t_{\infty}$ when the last survivor dies.

This equation can be rearranged as:

$$
\log _{\mathrm{e}}\left(1-D_{t} / \mathrm{N}_{\mathrm{r}}\right)=-M-m \cdot t
$$

or, because the fraction surviving to time $t$ is $\left(1-D_{t} / \mathrm{N}_{\mathrm{r}}\right)$ $=S_{t}, \log _{\mathrm{e}} S=-M-m \cdot t$ or $-\left(\log _{\mathrm{e}} S\right)=M+\mathrm{m} \cdot t$

Thus, if the natural logarithm of the fraction of $\mathrm{N}_{\mathrm{r}}$ remaining after successive time intervals is plotted against the time intervals, $t$, the result should be a straight line with a slope equal to $\mathrm{m}$ and which intersects the $y$-axis at a value equal to $M$, the mortality rate at the time of settlement.

\section{RESULTS}

\section{Settlement}

In September 1999 a very marked peak in settlement was noted at new moon, with abundances of 1.5 to $3.5 \mathrm{~cm}$ Ocyurus chrysurus on the experimental grid going from 5 to 92 in $9 \mathrm{~d}$ preceding new moon. A rapid decline followed (Fig. 1). In April-May and June-July 2000 peak abundance was much lower at 28 and 25 individuals, respectively. Note that in June-July the peak was either at or slightly before the new moon, but no observations were possible during that period and our first census gave the peak abundance for this month. Thus actual peak abundance may have been underestimated. In all of the 3 lunar cycles, the distribution of new settlers at peak abundance appeared clumped and, in 2, the distribution was significantly different from random. In September-October 1999, mean abundance at peak settlement was 1.84 fish per $25 \mathrm{~m}^{2}$ sampling square (variance $=4.54$, chi-squared goodness of fit $\mathrm{p}<0.01$ ). In April-May the mean was 


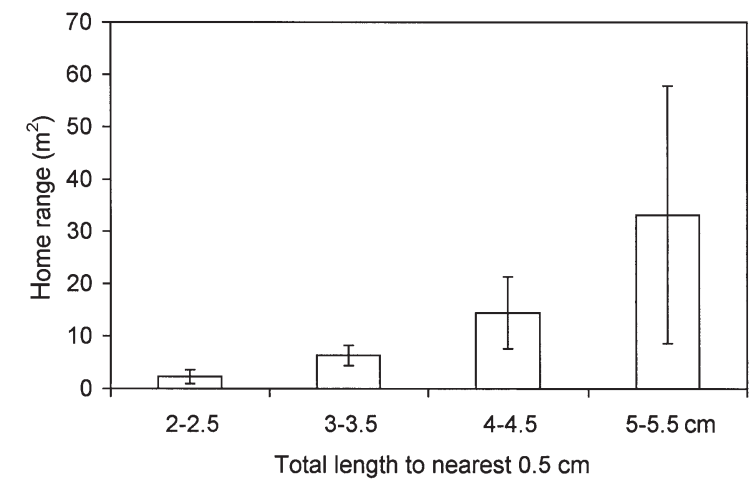

Fig. 2. Mean home range size for Ocyurus chrysurus of a total length 2 to $2.5,3$ to $3.5,4$ to 4.5 and 5 to $5.5 \mathrm{~cm}(\mathrm{n}=11,7,4$ and 4 , respectively). Error bars represent standard deviation

0.56 per square (variance $0.78, \mathrm{p}=0.6$ ) and in JuneJuly the mean was 0.50 (variance $=0.43, p=0.04$ ).

\section{Movement}

As a general case, Ocyurus chrysurus of $>7.5 \mathrm{~cm}$ TL were not in the seagrass by day and were found in the adjacent rocky habitat. Fish of 2 to $2.5 \mathrm{~cm}$ TL hung in the water column amidst blades of seagrass and picked at passing plankton while fish from about $3.5 \mathrm{~cm}$ TL foraged for benthic invertebrates (pers. obs.). We observed that 2 to $3 \mathrm{~cm}$ fish generally tolerated conspecifics of the same size, but fish $\geq 3.5 \mathrm{~cm}$ were aggressive to similarly sized fish and wary of larger individuals.

Fish $<7.5 \mathrm{~cm}$ were always seen in the seagrass and never on the reef. Thus early juveniles were considered to be resident in the seagrass. Indeed, movement studies of individuals confirmed that even fish up to $5.5 \mathrm{~cm}$ TL had fairly restricted home ranges (Fig. 2), and recently settled fish $\leq 3.5 \mathrm{~cm}$ TL had mean home ranges of only $6.3 \mathrm{~m}^{2}$, nearly 200 times less than the overall area regularly censused. We therefore considered the number of home ranges on the edge of the grid, where fish would be sometimes in and sometimes out of the census, likely to be insignificant compared to the overall number of fish with ranges completely within the grid.

To check if fish demonstrated site fidelity in their home ranges, we examined the distribution of re-sightings of elastomer-tagged fish. Fig. 3 shows the positions of 32 re-sightings between 9 and 17 September. Of the 96 fish released on 6 to 8 September, only 8 fish (the maximum seen on 1 day) were seen on 9 September. All but 1 of the subsequent re-sightings were within a few metres of a sighting on 9 September, suggesting that although on release many fish may have dispersed to areas outside the grid before settling (the grid extended only $12.5 \mathrm{~m}$ from the release spot in 2 directions), and not all tagged fish would have been spotted in each census, home ranges remained in the same location.

Of the 23 elastomer-tagged fish released inside a $45 \mathrm{~cm}$ high fence in April-May, only 3 remained after $2 \mathrm{~d}$. None were seen outside the fence on Day 2 or on the 12 subsequent censuses, despite careful searching. One tagged fish remained inside the fence $23 \mathrm{~d}$ later. The tagged fish therefore either swam over the fence and moved out of the survey area or they were consumed by predators that entered the $16 \mathrm{~m}^{2}$ enclosure.

\section{Mortality}

Since movement of recently settled Ocyurus chrysurus was found to be negligible in the first few weeks of life, abundances were assumed directly proportional to survival. We attempted to fit simple exponential and power curves to the data from all 3 lunar cycles (Fig. 1), but neither type provided a good fit when forced to go through the initial abundances observed.

Using the equation described in the preceding section, we plotted the natural logarithms of survival 9th

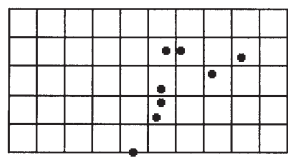

10 th

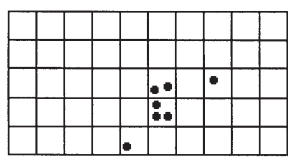

11 th

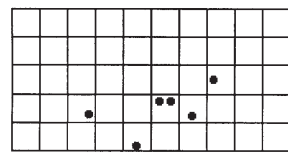

12th

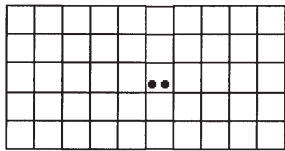

13 th

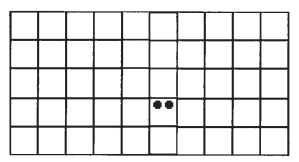

14 th

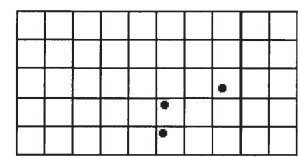

15 th

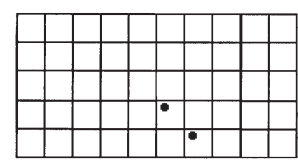

16 th

17 th

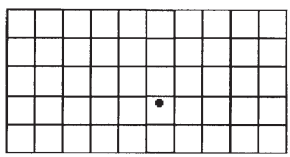

18 th

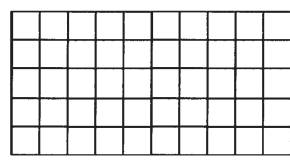

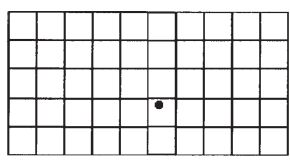

Fig. 3. Schematic diagrams of a $50 \mathrm{~m} \times 25 \mathrm{~m}$ grid in a seagrass bed where 96 elastomer-tagged, recently settled Ocyurus chrysurus were released between the nights of 6 and 8 September 1999. Dots represent 32 re-sightings of tagged fish on subsequent censuses between 9 and 18 September 1999 

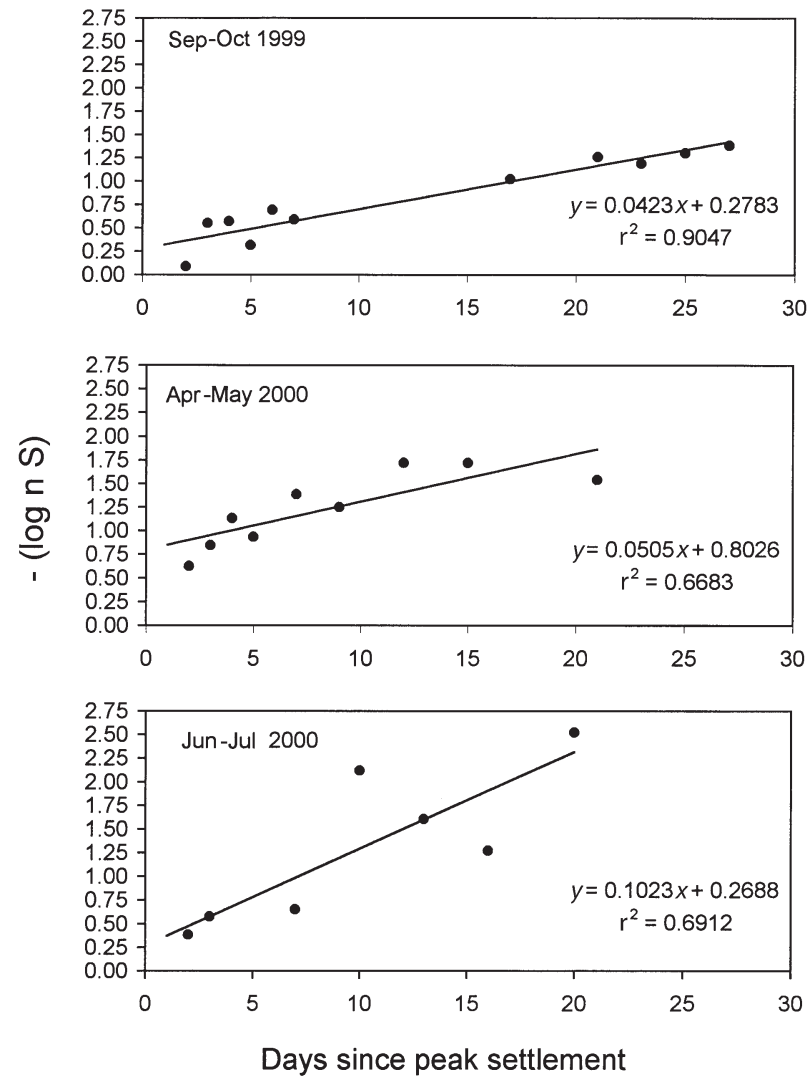

Fig. 4. Regressions of the natural logarithm of the survival rate to time $t$ plotted against days since peak settlement. Slope is the daily amount, $m$, by which natural mortality decreases with increasing age, and the $y$-axis intercept equals the natural mortality rate, $M$, at settlement

against time since peak settlement for each of the observed cohorts (Fig. 4). The data for the SeptemberOctober cohort gives a good fit $\left(\mathrm{r}^{2}=0.905\right)$ and we derived estimates of $m=-0.0423$ and $M=-0.2783$. If the mortality coefficient $M$ decreases at a constant rate as suggested by the straight-line relationship when log survival is plotted against time, the value of $M$ derived from the intercept of this graph is an estimate of mortality at the moment of settlement. For the September cohort, the instantaneous daily mortality rate, $M$, at settlement is therefore -0.2783 , equivalent to a fractional survival of $76 \% \mathrm{~d}^{-1}$. The equation also predicts that survival to $7 \mathrm{~d}$ and $30 \mathrm{~d}$ would be about $56 \%$ and $21 \%$, respectively. These estimates of the mortality rates are somewhat conservative because, as explained previously, a few additional settlers might have arrived in the study area in the period after new moon. These estimates of survival therefore represent maximum values.

Owing to the small numbers of fish that settled in April and June, the estimates are less reliable $\left(\mathrm{r}^{2}=\right.$
0.668 and 0.691, respectively). For the April-May cohort, $m=-0.0505$ and $M=-0.8026$. Thus only $42 \%$ survived the first day after settlement and survival to $30 \mathrm{~d}$ would be about $10 \%$. For the June cohort, $m=$ -0.1023 and $M=-0.2688$. Post-settlement survival would be $69 \%$ after the first day and about $4 \%$ to $30 \mathrm{~d}$.

The validity of these first estimates can be checked by using them to construct a matrix which estimates the fraction of the numbers of fish observed each day that would survive to successive days, starting $7 \mathrm{~d}$ before new moon and ending $7 \mathrm{~d}$ after new moon (the period for which continuous daily observations were made for the September-October cohort). From this, the number of fish actually settling each day can be calculated. These calculations suggest that about 240 fish settled into the study area over a $15 \mathrm{~d}$ period, of which only $23(<10 \%)$ survived to $26 \mathrm{~d}$ after the new moon. This suggests that the mortality rates calculated from the data are conservative. However, the data are too variable to refine the estimates iteratively.

The tagging data also yield information on mortality rates. Allowing for $13 \%$ mortality induced by tagging and handling, the 2 experiments suggest 10 to $15 \%$ survival after $2 \mathrm{~d}$, followed by a lower rate of attrition. This is a lower post-settlement survival than is indicated by the preceding analysis. However, the small numbers of fish involved preclude more detailed analyses. Additionally, the tagged fish were released en masse during the day, which differs from the natural situation. Also, these were fish that were in the pre-settlement stage when caught and it is possible that they mostly dispersed in the water column when released.

\section{DISCUSSION}

Ocyurus chrysurus appeared to undergo a 2-phase recruitment process (sensu Finn \& Kingsford 1996) whereby early juvenile fish subject to high post settlement mortality are relatively sedentary in seagrass for several weeks, before moving to more rugose habitat as older juveniles. Ogden \& Zieman (1977) considered $O$. chrysurus juveniles to be resident in seagrasses, and other researchers have found similar 2-step patterns for various species and habitats (Baelde 1990, Eggleston 1995, Green 1996, McCormick \& Makey 1997 and references therein, Nagelkerken et al. 2000a,b, 2001). Nagelkerken (2000b) found that O. chrysurus uses seagrass exclusively up to $2.5 \mathrm{~cm}$ TL and thereafter moves progressively into mangroves and other habitats, and suggested that they are obligate dependents on seagrasses and mangroves. This cannot be entirely true, because they are found on oceanic banks with least depths of 30 to $40 \mathrm{~m}$ (Thompson \& Munro 
1983) and modest numbers must be able to survive in relatively deep coralline habitats.

Bertenshaw (2001) also found that newly settled Ocyurus chrysurus settled preferentially into seagrass beds, but also stands of Halimeda, sand holes and coral rubble. Thus, settlement preferences may vary spatially and/or temporally within species, perhaps as a function of settlement intensity (Booth \& Wellington 1998). Further, there are both limitations and advantages to our methods of estimating settlement, movement and survival that should be considered.

\section{Settlement}

Visual censuses are unlikely to have recorded all settlement-stage fish. Some will always be missed, and numbers observed may depend on a variety of factors. For example, the sharp dip in abundance on 12 and 13 October coincided with the close passage of a tropical storm, and decreased visibility. The apparent slight increases in abundance after about $2 \mathrm{wk}$ in the AprilMay and June-July data sets might be caused by a small influx of fish half-way through the cycle, but more likely are a chance variation in the small numbers observed.

It is possible that a few fish grew out of our size range, artificially inflating mortality estimates. However, from observing a rapid rather than a gradual transition of most fish between the $0.5 \mathrm{~cm}$ size classes, we consider this effect to be small. Further, it is likely to have been outweighed by a bias operating in the other direction. As numbers drop and an observer becomes more familiar with fish distribution, it becomes easier to spot fish that one expects to see than to spot randomly re-distributed individuals. Thus, abundance in the middle of the surveys may be overestimated relative to the initial abundance at peak settlement.

\section{Movement}

Our observations of early juvenile movement are restricted to the period immediately after settlement to the benthic habitat and do not extend into the period when juvenile snappers and grunts typically start to undergo diurnal migrations (Ogden \& Ehrlich 1977, Ogden \& Zieman 1977, Weinstein \& Heck 1979, Helfman et al. 1982). Once settled, Ocyurus chrysurus appeared to establish consistent home ranges and did not move far. Fish did not appear to re-enter the water column once settled, although we cannot rule out saltatory settlement for fish that settle to other, perhaps less suitable habitats.
Of the 92 elastomer-tagged fish released on the experimental grid over 6 to 8 September, only 32 were re-sighted and most of these are thought to have been multiple re-sightings of the 8 fish (the maximum recorded) seen the day after the final release. If movement was so limited, what happened to the other fish? Tag-related mortality (13\%) would have accounted for some losses. In addition, marked fish may have suffered increased predation due to their increased visibility. Notably, the biggest batch of fish (released on 6 September) was at large for $2 \mathrm{~d}$ before counts were started. Since mortality is highest immediately after settlement, these fish could have been disproportionately affected. Further, a significant proportion of fish presumably dispersed off the grid before choosing a settlement microhabitat, as the nearest 2 edges were only $12.5 \mathrm{~m}$ distant from the release point and at least 1 of the repeatedly re-sighted fish was seen at the edge of the grid. As mentioned previously, these were late pre-settlement fish that had not voluntarily settled, and it is possible that a substantial proportion returned to the water column, dispersed and settled elsewhere.

There is little information on movement of early juvenile snappers for comparison with our results. Mori (1984) studied the early life history of Lutjanus vitta in the Sea of Japan, and Frederick (1997a) studied transplanted L. kasmira on an array of isolated artificial reefs in Hawaii, noting a strong tendency to move straight after release. Early juveniles clearly had the ability to move at least $100 \mathrm{~m}$. However, fish were collected from outlying artificial habitats several days after settlement, and transplanted to the center of the array. Direction of movement was significantly correlated with the direction of home reefs, and movement (and also survival) was strongly related to fish size. In addition, Frederick notes that L. kasmira schooled freely over arrays of artificial habitats of 2 and $5 \mathrm{~m}$ radius. Thus the behaviour of this fish appears quite different from Ocyurus chrysurus.

Since movement in our study was minimal, we feel confident in assuming decreases in observed abundance reflect mortality.

\section{Mortality}

Other researchers have used similar visual techniques to estimate mortality (e.g. Sale \& Ferrell 1988, Booth 1991, McGehee 1995), and our study has advantages recognized by several authors, for example frequent censuses (Booth 1991, Caley et al. 1996, Levin 1998), at least 1 large cohort (Sale \& Ferrell 1988), a relatively large census area to take account of varying predation between microhabitats (e.g. Beukers \& Jones 1997, Nemeth 1998), and a lack of tagging arti- 
facts (Bergman et al. 1992) since tagged fish were not used for mortality estimates (see below). Additionally, most previous studies have used artificial or manipulated habitats (Shulman et al. 1983, Risk 1997, 1998, Frederick 1997a, Finn \& Kingsford 1996, Beets 1997, Connell 1997, but see Caselle 1999) that may not always accurately represent natural environments (Connell 1997).

Our study concurs with a growing body of research that emphasizes the importance of post-settlement mortality in structuring populations (Shulman \& Ogden 1987, Warner \& Hughes 1988, Jones 1991, Connell 1998, Caselle 1999). Our strongest data set is for September-October 1999, where mortality for recently settled Ocyurus chrysurus was estimated at $79 \%$ over 30 d. Data from April-May and June-July 2000 show a similar pattern in the plot of log survival against time (Fig. 4). However, the initially low abundance at peak settlement magnifies the effects of variation in counts when converted into proportions or percentages, reducing confidence in the slope of the fitted line. Mortality estimates from such small samples sizes may be seriously flawed (Caley 1998). Thus we have insufficient data for a full analysis of the effects of settlement density on survival. Nonetheless, in the simplest sense it is noteworthy that actual numbers surviving were higher in September when supply was approximately 3 times greater than in April-May and June-July (peak abundances 92, 28 and 25, respectively), suggesting mortality may show density independence or undercompensating density dependence. Use of different habitats by early juvenile and older juvenile fish (here seagrass and high relief structures such as reefs and mangroves, respectively) lowers the likelihood of density-dependent feedback on early juvenile survival (Schmitt \& Holbrook 1996).

\section{Implications for recovery interventions in severely overexploited stocks}

Post-settlement mortality is generally recognized as high for coral reef fish (Roberts 1996 and references therein). Actual mortality values can vary greatly between species and even sites. For example, Sale \& Ferrell (1988) estimated that survivorship during the first week after recruitment for 17 coral reef species was as high as $90 \%$ or as low as $50 \%$, and Beukers \& Jones (1997) found that juvenile mortality of the damselfish Pomacentrus moluccensis over the first year of life varied between 20 and $100 \%$ among sites. Caselle (1999) found very variable mortality of Thalassoma bifasciatum at 8 sites around St. Croix, USVI. She found evidence for density-dependent mortality during the first few days of benthic life above a threshold settlement density. After that, mortality was densityindependent. Shulman \& Ogden (1987) estimated that post-settlement mortality for Caribbean grunts is $90 \%$ within a month and concluded that, whether or not mortality is density-dependent, factors controlling benthic mortality are more important in determining population dynamics than variations in settlement. Further, the mortality rates during the settlement process, i.e. while the fish are in the water over settlement habitat but before they actually switch to the benthic environment, are presently unquantified but are probably extremely high (Kaufman et al. 1992).

However, where density-dependent effects are weak, both larval supply and early juvenile mortality will be important in controlling adult populations (Connell 1998). Thus, to effectively enhance severely depleted populations, a combined approach that increases supply of settlers and decreases early mortality may be most effective. Doherty (1994) suggested settlement stage reef fish caught with light traps could be used to supplement natural populations. Watson et al. (2001) proposed a relatively simple rearing system to raise such fish beyond their early juvenile 'mortality hurdle' for subsequent release into 'no-fishing' marine protected areas. Preliminary tests of this system found mortality of snappers stabilized at approximately $20 \%$ after 2 wk (R. Power unpubl. data). This can be compared with the estimate of at least $60 \%$ loss in $2 \mathrm{wk}$ observed in the present study. Note that for increased survival to aid stock recovery, overall survival must be improved for all life history stages from release through to maturity (Heppell \& Crowder 1998). This has not yet been demonstrated for such an approach. Importantly, if overfishing originally caused a stock collapse, any intervention must be in concert with reduction of effort and with habitat protection (e.g. through marine protected areas). It is essential that lawmakers and the public don't see enhancement as an alternative to improved stewardship (Scarnecchia 1988, Meffe 1992).

Nonetheless, even where fish mortality remains high and the per capita costs of interventions appear substantial, the value of enhancement should be considered in terms of survivor reproductive potential rather than a direct contribution to stock numbers (Stoner \& Glazer 1998). Further, for new management regimes to gain long-term acceptance amongst communities depending on reefs, positive results need to be demonstrable within a few years. For recruitment-overfished reef ecosystems without a reliable and productive upstream source of fish larvae, interventions to accelerate recovery may be the only alternative to waiting for decades for the meagre-remnant local stocks to build up to the point where they can provide natural replenishment. 
Acknowledgements. Funding for this study was provided by the United Kingdom's Department for International Development. R. Power, J. Lawn, S. Fredericke, S. Simpson, G. Hassidis and staff from the BVI Conservation and Fisheries Department assisted with light trapping. This is ICLARM Contribution No. 1615.

\section{LITERATURE CITED}

Baelde P (1990) Differences in the structure of fish assemblages in Thalassia testudinum beds in Guadeloupe, French West Indies, and their ecological significance. Mar Biol 105:163-173

Beets J (1997) Effects of a predatory fish on the recruitment and abundance of Caribbean coral reef fishes. Mar Ecol Prog Ser 148:11-21

Bergman PK, Haw F, Blankenship HL, Buckley RM (1992) Perspectives on the design, use and misuse of fish tags. Fisheries 17:20-25

Bertenshaw VJ (2001) Settlement bahaviour and survivorship of Ocyurus chrysurus (yellowtail snapper) and other juvenile reef fish species of the British Virgin Islands. MSc thesis, University of Plymouth

Beukers JS, Jones GP (1997) Habitat complexity modifies the impact of piscivores on a coral reef fish population. Oecologia 114:50-59

Booth DJ (1991) The effects of sampling frequency on estimates of recruitment of the domino damselfish Dascyllus albisella. J Exp Mar Biol Ecol 145:149-159

Booth DJ, Brosnan DM (1995) The role of recruitment dynamics in rocky shore and coral reef fish communities. Adv Ecol Res 26:309-385

Booth DJ, Wellington G (1998) Settlement preferences in coral-reef fishes: effects on patterns of adult and juvenile distributions, individual fitness and population structure. Aust J Ecol 23:274-279

Caley MJ (1993) Predation, recruitment and the dynamics of communities of coral-reef fishes. Mar Biol 117:33-43

Caley MJ (1995) Reef-fish community structure and dynamics: an interaction between local and larger-scale processes? Mar Ecol Prog Ser 129:19-29

Caley MJ (1998) Age-specific mortality rates in reef fishes: evidence and implications. Aust J Ecol 23:241-245

Caley MJ, Carr MH, Hixon MA, Hughes TP, Jones GP, Menge BA (1996) Recruitment and the local dynamics of open marine populations. Annu Rev Ecol Syst 27:477-500

Carr MH, Hixon MA (1995) Predation effects on early postsettlement survivorship of coral-reef fishes. Mar Ecol Prog Ser 124:31-42

Caselle JE (1999) Early post-settlement mortality in a coral reef fish and its effect on local population size. Ecol Monogr 69:177-194

Connell SD (1997) The relationship between large predatory fish and recruitment and mortality of juvenile coral reeffish on artificial reefs. J Exp Mar Biol Ecol 209:261-278

Connell SD (1998) Effects of predators on growth, mortality and abundance of a juvenile reef-fish: evidence from manipulations of predator and prey abundance. Mar Ecol Prog Ser 169:251-261

Cowen RK, Lwiza KMM, Sponaugle S, Paris CB, Olson DB (2000) Connectivity of marine populations: open or closed? Science 287:857-859

Doherty PJ (1994) A potential role for light-traps in enhancement of coral reef fisheries. In: Munro JL, Munro PE (eds) The management of coral reef resource systems. ICLARM Conf Proc 44, Manila, p 92-93
Doherty PJ (1999) Recruitment limitation as the theoretical basis for stock enhancement. In: Howell BR, Moksness E, Svasand $\mathrm{T}$ (eds) Stock enhancement and sea ranching. Blackwell Science, Oxford, p 9-21

Doherty P, Fowler T (1994) An empirical test of recruitment limitation in a coral reef fish. Science 263:935-939

Doherty PJ, Williams DM (1988) The replenishment of coral reef fish populations. Oceanogr Mar Biol Annu Rev 26: 487-551

Eggleston DB (1995) Recruitment in Nassau grouper Epinephelus striatus: post settlement abundance, microhabitat features, and ontogenetic habitat shifts. Mar Ecol Prog Ser 124:9-22

Finn MD, Kingsford MJ (1996) Two-phase recruitment of apogonids (Pisces) on the Great Barrier Reef. Mar Freshw Res 47:423-432

Forrester G (1995) Strong density-dependant survival and recruitment regulate the abundance of a coral reef fish. Oecologia 103:275-282

Forrester G, Steele M (2000) Variation in the presence and cause of density dependent mortality in three species of reef fishes. Ecology 81:2416-2427

Frederick JL (1997a) Post-settlement movement of coral reef fishes and bias in survival estimates. Mar Ecol Prog Ser 150:65-74

Frederick JL (1997b) Evaluation of fluorescent elastomer injection as a method for marking small fish. Bull Mar Sci 61:399-408

Green AL (1996) Spatial, temporal and ontogenetic patterns of habitat use by coral reef fishes (family Labridae). Mar Ecol Prog Ser 133:1-11

Helfman G, Meyer J, McFarland WN (1982) The ontogeny of twilight migration patterns in grunts (Pisces Haemulidae). Anim Behav 30:317-326

Heppell SS, Crowder LB (1998) Prognostic evaluation of enhancement programs using population models and life history analysis. Bull Mar Sci 62:495-507

Hilborn R (1998) The economic performance of marine stock enhancement projects. Bull Mar Sci 62:661-674

Hixon MA, Beets JP (1989) Shelter characteristics and Caribbean fish assemblages: experiments with artificial reefs. Bull Mar Sci 44:666-680

Hixon MA, Beets JP (1993) Predation, prey-refuges, and the structure of coral-reef fish assemblages. Ecol Monogr 63: $77-101$

Jennings S, Lock JM (1996) Population and ecosystem effects of reef fishing. In: Polunin NVC, Roberts CM (eds) Management of reef fisheries. Chapman \& Hall, London, p 193-218

Jones GP (1991) Postrecruitment processes in the ecology of coral reef fish populations: a multifactoral perspective. In: Sale PF (ed) The ecology of fishes on coral reefs. Academic Press, San Diego, p 294-330

Kaufman L, Ebersole J, Beets J, McIvor CC (1992) A key phase in the recruitment dynamics of coral reef fishes: post settlement transition. Env Biol Fish 34(2):109-118

Leber KM, Arce SM, Sterritt DA, Brennan NP (1996) Marine stock-enhancement potential in nursery habitats of striped mullet, Mugil cephalus in Hawaii. Fish Bull 94:452-471

Levin PS (1998) The significance of variable and densityindependant post-recruitment mortality in local populations of reef fishes. Aust J Ecol 23:246-251

McCormick MI, Makey LJ (1997) Post-settlement transition in coral reef fishes: overlooked complexity in niche shifts. Mar Ecol Prog Ser 153:247-257

McFarland WN, Brothers EB, Ogden JC, Shulman MJ, Bermingham EL, Kotchian-Prentiss NM (1985) Recruit- 
ment patterns in young French grunts, Haemulon flavolineatum (Family Haemulidae) at St. Croix, USVI. Fish Bull 83:413-426

McGehee MA (1995) Juvenile settlement, survivorship and in situ growth rates of four species of Caribbean damselfish in the genus Stegastes. Environ Biol Fish 44:393-401

Meffe GK (1992) Techno-arrogance and halfway technologies: salmon hatcheries on the Pacific coast of North America. Conserv Biol 6:350-354

Menge BA, Sutherland JP (1987) Community regulation: variation in disturbance, competition and predation in relation to environmental stress and recruitment. Am Nat 130: 730-757

Mori (1984) Early life history of Lutjanus vitta (Lutjanidae) in Yuya Bay, the Sea of Japan. Jpn J Ichthyol 30:347-392

Munro JL, Bell JD (1997) Enhancement of marine fisheries resources. Rev Fish Sci 5:185-222

Munro JL, Watson M (1999) Caribbean Marine Protected Areas Project: the role of marine protected areas in fisheries management and biodiversity conservation in coral reef ecosystems. ICLARM Caribbean Marine Protected Areas Project Technical Report

Nagelkerken, I, Dorenbosch M, Verbeck WCEP, Cocheret de la Morinière E, van der Velde G (2000a) Importance of shallow-water biotopes of a Caribbean bay for juvenile coral reef fishes: patterns in biotope association, community structure and spatial distribution. Mar Ecol Prog Ser 202:175-192

Nagelkerken I, van der Velde G, den Hartog C (2000b) Importance of mangroves, seagrass beds and the shallow coral reef as a nursery for important coral reef fishes, using a visual census technique. Estuar Coast Shelf Sci 51:31-44

Nagelkerken I, Kleijnen S, Klop T, van den Brand RACJ, Cocheret de la Morinière E, van der Velde G (2001) Dependence of Caribbean reef fishes on mangroves and seagrass beds as nursery habitats: a comparison of fish faunas between bays with and without mangroves/seagrass beds. Mar Ecol Prog Ser 214:225-235

Nemeth RS (1998) The effect of natural variation in substrate architecture on the survival of juvenile bicolor damselfish. Environ Biol Fish 53:129-141

Odum EP, Kuenzler EJ (1955) Measurement of territory and home range size in birds. Auk 72:128-137

Ogden JC, Ehrlich PR (1977) The behaviour of heterotypic resting schools of juvenile grunts (Pomadasyidae). Mar Biol 42(3):273-280

Ogden JC, Zieman JC (1977) Ecological aspects of coral reef-seagrass bed contacts in the Caribbean. Proc 3rd Int Coral Reef Symp, 1:377-382

Planes S, Lecaillon G (1998) Evidence of high predation in

Editorial responsibility: Otto Kinne (Editor),

Oldendorf/Luhe, Germany new fish recruits within the first night: a caging experiment. In: Abstracts. International Society for Reef Studies 1998 European Meeting, Perpignan

Risk A (1997) Effects of habitat on the settlement and postsettlement success of the ocean surgeonfish Acanthurus bahianus. Mar Ecol Prog Ser 161:51-59

Risk A (1998) The effects of interactions with reef residents on the settlement and subsequent persistence of ocean surgeonfish, Acanthurus bahianus. Environ Biol Fish 51: $377-389$

Roberts CM (1996) Settlement and beyond: population regulation and community structure of reef fishes. In: Polunin NVC, Roberts CM (eds) Reef fisheries. Chapman \& Hall, London, $\mathrm{p}$ 85-112

Sale PF, Ferrel DJ (1988) Early survivorship of juvenile coral reef fishes. Coral Reefs 7:117-124

Scarnecchia DL (1988) Salmon management and the search for values. Can J Fish Aquat Sci 45:2042-2050

Schmitt RJ, Holbrook SJ (1996) Local-scale patterns of larval settlement in a planktivorous damselfish-do they predict recruitment? Mar Freshw Res 47:449-463

Schramm HLJ, Piper RG (1995) Uses and effects of cultured fishes in aquatic ecosystems. Am Fish Soc Symp 15:608

Shenker JM, Maddox ED, Wishinski E, Pearl A, Thorrold SR, Smith N (1993) Onshore transport of settlement stage Nassau grouper Epinephelus striatus and other fishes in Exuma Sound, Bahamas. Mar Ecol Prog Ser 98:31-43

Shulman MJ, Ogden JC (1987) What controls tropical reef fish populations: recruitment or benthic mortality? An example in the Caribbean reef fish Haemulon flavolineatum. Mar Ecol Prog Ser 39:233-242

Shulman MJ, Ogden JC, Ebersole JP, McFarland WN, Miller SL, Wolf NG (1983) Priority effects in the recruitment of juvenile coral reef fishes. Ecology 64:1508-1513

Stoner AW, Glazer RA (1998) Variation in natural mortality: implications for Queen conch stock enhancement. Bull Mar Sci 62:427-442

Thompson R, Munro JL (1983) The biology, ecology and bionomics of the snappers, Lutjanidae. In: Munro JL (ed) Caribbean coral reef fishery resources. ICLARM Studies and Reviews 7, Manila, p 94-109

Warner RR, Hughes TP (1988) The population dynamics of reef fishes. Proc 6th Int Coral Reef Symp 1:146-155

Watson M, Power R, Munro JL (2001) Use of light-attracted zooplankton for rearing post-settlement coral reef fish. Proc Gulf Caribb Fish Inst 52:340-351

Weinstein MP, Heck KL Jr (1979) Ichthyofauna of seagrass meadows along the Caribbean coast of Panama and the Gulf of Mexico: composition, structure and community ecology. Mar Biol 50:97-107

Submitted: May 22, 2001; Accepted: March 12, 2002

Proofs received from author(s): June 17, 2002 